\title{
ON WEIGHTED SIMPSON TYPE INEQUALITIES AND APPLICATIONS
}

\author{
Kuei-Lin Tseng, Gou-Sheng Yang And Sever S. Dragomir
}

Abstract. In this paper we establish some weighted Simpson type inequalities and give several applications for the $r$-moments and the expectation of a continuous random variable. An approximation for Euler's Beta mapping is given as well.

Mathematics subject classification (2000): 26D15, 26D10, 41A55.

Key words and phrases: Simpson inequality, weighted inequalities, quadrature rules.

\section{REFERENCES}

[1] T. M. Apostol, Mathematical Analysis, Second Edition, Addision-Wesley Publishing Company, 1975.

[2] D. Cruz-Urible AND C. J. Neugebauer, Sharp error bounds for the trapezoidal rule and Simpson's rule, J. Inequal. Pure Appl. Math. 3 (2002), no. 4, Article 49, 22 pp. [Online: http://jipam.vu.edu.au/v3n4/031_02.html].

[3] V. ČUlJaK, J. PeČARIĆ AND L. E. Persson, A note on Simpson's type numerical integration, Soochow J. Math. 29 (2003), no. 2, 191-200.

[4] S. S. DRAGOMIR, On Simpson's quadrature formula and applications, Mathematica 43 (66) (2001), no. 2, 185-194.

[5] S. S. DRAGOMIR, On Simpson's quadrature formula for Lipschitzian mappings and applications, Soochow J. Math. 25 (1999), no. 2, 175-180.

[6] S. S. DRAGOMIR, On Simpson's quadrature formula for mappings of bounded variation and applications, Tamkang J. of Math. 30 (1999), no. 1, 53-58.

[7] S. S. DRAGOmiR, R. P. Agarwal AND P. CERONE, On Simpson's inequality and applications, J. Inequal. Appl. 5(2000), no. 6, 533-579.

[8] L. FeJÉR, Uberdie Fourierreihen, II, Math. Natur. Ungar. Akad Wiss. 24 (1906), 369-390. [In Hungarian].

[9] J. PEČARIĆ AND S. VAROŠANEC, A note on Simpson's inequality for Lipschitzian functions, Soochow J. Math. 27 (2001), no. 1, 53-57.

[10] J. PeČARIĆ AND S. VAROŠANEC, A note on Simpson's inequality for functions of bounded variation, Tamkang J. of Math. 31(2000), no. 3, 239-242.

[11] N. UJEVIĆ, New bounds for Simpson's inequality, Tamkang J. of Math. 33(2002), no. 2, 129-138.

[12] G. S. YANG AND H. F. ChU, A note on Simpson's inequality for function of bounded variation, Tamsui Oxford J. Math. Sci. 16 (2000), no. 2, 229-240. 